\title{
Pengaruh Faktor Sosial Ibu terhadap Keberhasilan Menyusui pada Dua Bulan Pertama
}

\section{Influence of Mother's Social Factors and Breastfeeding Success in the First Two Months}

\author{
Wirawati Amin 1 , I Wayan Agung I', Endang Sri W \\ ${ }^{1}$ Program Magister Kebidanan Fakultas Kedokteran Universitas Brawijaya Malang \\ ${ }^{2}$ Laboratorium Obstetri-Ginekologi Rumah Sakit Umum Daerah Dr. Saiful Anwar Malang \\ ${ }^{3}$ Laboratorium Ilmu Faal Fakultas Kedokteran Universitas Brawijaya Malang
}

\begin{abstract}
ABSTRAK
Tingkat keberhasilan pemberian Air Susu Ibu pada dua bulan pertama masih rendah, padahal masa ini merupakan masa percepatan pertumbuhan pada bayi, disaat kebutuhan bayi meningkat. Penelitian ini bertujuan untuk menganalisis pengaruh faktor sosial ibu meliputi umur, pendidikan, pekerjaan, pengetahuan, Inisiasi Menyusu Dini (IMD), dukungan suami dan teknik menyusui terhadap keberhasilan menyusui pada dua bulan pertama di RSKDIA Pertiwi Makassar. Metode penelitian ini adalah observasional analitik, dengan purposive sampling sebanyak 131 di Rumah Sakit Khusus Daerah Ibu dan Anak Pertiwi Makassar pada Oktober 2013-Januari 2014. Pengukuran teknik menyusui digunakan lembar observasi/check list yang dinilai oleh peneliti sendiri, sedangkan penilaian keberhasilan menyusui dilakukan melalui kunjungan rumah setelah subjek pulang dari Rumah Sakit, yakni pada satu minggu, dua minggu dan delapan minggu setelah subjek melahirkan, dengan menggunakan kuesioner. Analisis hasil penelitian menggunakan uji Chi-Square. Hasil penelitian menemukan ada pengaruh positif antara pendidikan $(p=0,006 ; O R=2,826)$, pekerjaan $(p=0,001 ; O R=0,293)$, pengetahuan $(p=0,000 ; O R=14,792)$, IMD $(p=0,000 ; O R=6,771)$, dukungan suami $(p=0,000 ; O R=10,988)$ dan teknik menyusui ( $p=0,001 ; O R=3,784)$ terhadap keberhasilan menyusui pada dua bulan pertama. Hasil penelitian ini menyimpukan bahwa ibu dengan tingkat pendidikan tinggi, tidak bekerja, mempunyai pengetahuan yang baik, melaksanakan IMD, mempunyai dukungan aktif dari suami, memiliki teknik menyusui yang baik dapat meningkatkan keberhasilan menyusui pada dua bulan pertama.
\end{abstract}

Kata Kunci: Air Susu Ibu, faktor sosial ibu, keberhasilan menyusui dua bulan pertama

\begin{abstract}
The success rate of breastfeeding in the first two months is still low, whereas this stage is a stage of accelerated growth in babies. This study aims to analyze the influence of maternal social factors including age, education, occupation, knowledge, early initiation of breastfeeding, husband's support, and feeding techniques to successfully breastfeed in the first two months in RSKDIA Pertiwi Makassar. The research method was an observational analytic study, with purposive sampling as many as 131 in Pertiwi Maternal and Child Special Hospital Makassar from October 2013 to January 2014. Breastfeeding technique measurement was using observation sheet/check list assessed by the researchers themselves, while the successful breastfeeding assessment was using questionnaire through home visits after the subjects were home, which were at one week, two weeks and eight weeks after subjects gave birth. Analyses of the research results were using Chi-Square. The study finds positive relationship between education $(p=0,006 ; 0 R=2,826)$, occupation ( $p=0,001$; $O R=0,293)$, knowledge ( $p=0,000 ; O R=14,792)$, early initiation of breastfeeding ( $p=0,000 ; 0 R=6,771)$, husband's support $(p=0,000 ; O R=10,988)$ and feeding techniques $(p=0,001 ; O R=3,784)$ on the success of breastfeeding in the first two months. The results of this study concludes that mothers who have higher levels of education, do not work, have broad knowledge, implement the early initiation of breastfeeding, are supported actively by the husband, and have a good breastfeeding technique can improve the success of breastfeeding in the first two months.
\end{abstract}

Keywords: Breast milk, maternal social factors, breastfeeding success in the first two months

Jurnal Kedokteran Brawijaya, Vol. 28, No. 2, Agustus 2014; Korespondensi: Wirawati Amin. Program Magister Kebidanan Fakultas Kedokteran Universitas Brawijaya Malang, Jl. Veteran Malang Tel. (0341) 566117Email: wirawati_amin@yahoo.co.id 


\section{PENDAHULUAN}

Air Susu Ibu (ASI) merupakan pangan kompleks karena mengandung zat-zat gizi lengkap, yang merupakan nutrisi ideal untuk menunjang kesehatan, pertumbuhan dan perkembangan bayi secara optimal(1). ASI mengandung faktor-faktor anti infeksi yang dapat menurunkan risiko terjadinya penyakit infeksi, misalnya infeksi saluran napas, infeksi telinga, infeksi saluran kemih, diare dan pneumonia, serta penyakit lainnya seperti obesitas, diabetes, alergi dan penyakit inflamasi saluran cerna. Menyusui akan meningkatkan jalinan kasih sayang antara ibu dan bayi, meningkatkan kecerdasan dan perkembangan emosi yang lebih matang. Selain itu dengan menyusui akanmenurunkan risiko pendarahan paska melahirkan, kanker payudara dan kanker rahim(2).

Menyusui eksklusif berarti bayi hanya diberi ASI tanpa tambahan makanan atau minuman lain termasuk air putih (kecuali obat-obatan dan vitamin atau mineral tetes; ASI perah juga diperbolehkan). Organisasi Kesehatan Dunia (WHO) merekomendasikan pemberian ASI eksklusif untuk bayi sampai berumur 6 bulan dan kemudian dilanjutkan bersama makanan pendamping ASI sampai berumur 2 tahun atau lebih (4). Meskipun manfaat menyusui begitu besar, namun tidak banyak ibu yang menyusuibayinya secara eksklusif. Berdasarkan Survei Demografi Kesehatan Indonesia (SDKI) tahun 2006-2007 diperoleh data pemberian ASI pada bayi dibawah dua bulan sebesar $67 \%$, bayi usia $2-3$ bulan $54 \%$ dan 32,3\% sampai usia 6 bulan. Data yang diperoleh dari Riset Kesehatan Dasar (Riskesdas) tahun 2010 menunjukkan bahwa persentase bayi yang menyusu 1 bulan adalah $32,5 \%$, usia 2 bulan $30,7 \%$, usia 4 bulan 25,3\% dan sampai dengan 6 bulan $15,3 \%$. Hasil tersebut belum seperti yang diharapkan yaitu ibu menyusui eksklusif sampai 6 bulan pada tahun 2010 menjadi $80 \%$ (3).

Banyak faktor yang mempengaruhi pemberian ASI antara lain pengetahuan, ibu harus bekerja, ibu sakit, pengaruh iklan atau promosi susu formula, meniru teman yang memberikan susu formula, takut kehilangan daya tarik sebagai wanita, tekanan batin, kurangnya dukungan tenaga kesehatan, kesulitan bayi dalam menghisap serta ibu merasa produksi ASInya kurang (5). Penelitian yang dilakukan di Brazil mendapatkan bahwa faktor yang mempengaruhi ibu menyusui eksklusif pada 3 bulan pertama adalah pekerjaan ibu, pendidikan, pendapatan keluarga, dan penggunaan dot (6).

Di Indonesia, rata-rata ibu menyusui eksklusif hanya 2 bulan. Pada saat yang bersamaan, pemberian susu formula meningkat 3 kali lipat (7). Bayi pada dua bulan pertama kelahiran, yakni usia 3 minggu dan 6 minggu mengalami percepatan pertumbuhan (growth spurt), disaatkebutuhan bayi meningkat, frekuensi menyusu menjadi lebih sering dan durasi menyusui lebih lama dari biasanya. Pada masa ini seringkali ibu menduga produksi ASInya kurang sehingga cenderung memberikan tambahan makanan/minuman lain (8). Penelitian di Banyumas, mengemukakan bahwa faktor internal yang berhubungan dengan kegagalan pemberian ASI selama 2 bulan adalah ibu pekerja, pendidikan rendah, mindset ibu, paritas $\geq 3$, keadaan ibu sakit, kunjungan antenatal tidak lengkap, sedangkan faktor eksternal adalah persalinan tidak normal dan pengenalan awal susu formula/makanan pendamping ASI (9).
Survei yang dilakukan oleh Helen Keller International pada tahun 2002 juga menyebutkan bahwa rata-rata bayi di Indonesia hanya mendapatkan ASI eksklusif selama 1,7 bulan. Alasan yang menjadi penyebab ibu tidak menyusui bermacam-macam seperti misalnya budaya memberikan makanan pralaktal, memberikan tambahan susu formula karena ASI tidak keluar, menghentikan pemberian ASI karena bayi atau ibu sakit, ibu harus bekerja, serta ibu ingin mencoba susu formula (10). Tujuan dari penelitian ini adalah untuk mengetahui faktor sosial ibu meliputi umur, pendidikan, pekerjaan, pengetahuan, Inisiasi Menyusu Dini (IMD), dukungan suami dan teknik menyusui yang berpengaruh terhadap keberhasilan menyusui pada dua bulan pertama.

\section{METODE}

Penelitian ini adalah penelitian observasional analitik. Teknik pengambilan sampel dilakukan dengan metode non probability sampling yaitu purposive sampling. Sampel pada penelitian ini adalah ibu yang telah melahirkan dan dirawat di RSKDIA Pertiwi Makassar, yaitu 131 orang responden. Setiap subjek atau respondendiberikan kuesioner untuk diisi. Untuk mengobservasi teknik menyusui digunakan lembar observasi/check list yang dilakukan oleh peneliti sendiri. Keberhasilan menyusui pada dua bulan pertama dilakukan pemantauan selama dua bulan melalui kunjungan rumah. Keberhasilan menyusui yang dimaksud dalam penelitian ini adalah keberhasilan ibu memberikan hanya ASI saja kepada bayinya, tanpa tambahan makanan/minuman lain (kecuali obat dan vitamin) selama dua bulan pertama. Di ruang perawatan kebidanan calon subjek yang memenuhi kriteria inklusi diberi penjelasan terlebih dahulu tentang tujuan dan cara penelitian, mengisi kuesioner.Kriteria inklusinya yaitu: ibu yang melahirkan spontan dan dirawat di RSKDIA Pertiwi Makassar, ibu dalam keadaan sehat jasmani dan rohani, bersedia mengikuti jalannya penelitian serta berdomisili di kota Makassar. Peneliti melakukan pengamatan teknik menyusui pada ibu dengan menggunakan lembar observasi. Proses pemantauan dilakukan setelah pulang dari Rumah Sakit melalui kunjungan rumah. Pemantauan dilakukan pada 1 minggu, 2 minggu dan 8 minggu setelah melahirkan. Pemantauan dilakukan pada pemberian ASI pada bayiuntuk menilai keberhasilan menyusui pada dua bulan pertama. Data hasil penelitian yang telah diolah kemudian dianalisis dengan memakai statistik uji Chi-Square, dilanjutkan dengan odd ratio.

\section{HASIL}

Dari penelitian yang telah dilakukan selama periode Oktober 2013-Januari 2014 di ruang nifas RSKDIA Pertiwi Makassar, yang dilanjutkan dengan kunjungan ke rumah responden, didapatkan 77 orang $(58,8 \%)$ yang berhasil menyusui pada dua bulan pertama. Ibu yang tidak berhasil menyusui pada dua bulan pertama sebanyak 54 orang (41,2\%). Hasil uji Chi-Square menunjukkan bahwa dari semua faktor yang dikaji, faktor umur tidak berpengaruh terhadap keberhasilan menyusui pada dua bulan pertama $(p=0,572)$. Faktor yang berpengaruh terhadap keberhasilan menyusui pada dua bulan pertama adalah tingkat pendidikan $(p=0,006)$, status bekerja $(p=0,001)$, penerapan IMD $(p=0,000)$, dukungan suami $(p=0,000)$, pengetahuan $(p=0,000)$ dan teknik menyusui $(p=0,001$. 
Tabel 1. Gambaran faktor yang berpengaruh terhadap keberhasilan menyusui pada dua bulan pertama

\begin{tabular}{|c|c|c|c|c|c|}
\hline \multirow[b]{2}{*}{ Variabel } & \multicolumn{2}{|c|}{ Keberhasilan menyusui } & \multirow[t]{2}{*}{$p$-value } & \multirow[t]{2}{*}{ OR } & \multirow[t]{2}{*}{ RR } \\
\hline & $\begin{array}{c}\text { Berhasil } \\
(n=77)\end{array}$ & $\begin{array}{c}\text { Tidak } \\
\text { berhasil } \\
\text { ( } n=54)\end{array}$ & & & \\
\hline \multicolumn{6}{|l|}{ 1. Umur } \\
\hline$<20$ th & $3(3,9 \%)$ & $1(1,9 \%)$ & \multirow{3}{*}{0,572} & \multirow{3}{*}{-} & \multirow{3}{*}{-} \\
\hline $20-35$ th & $64(83,1 \%)$ & $43(79,6 \%)$ & & & \\
\hline$>35$ th & $10(13 \%)$ & $10(18,5 \%)$ & & & \\
\hline \multicolumn{6}{|l|}{ 2. Tingkat pendidikan } \\
\hline Rendah & $18(23,4 \%)$ & $25(46,3 \%)$ & \multirow[t]{2}{*}{0,006} & \multirow[t]{2}{*}{2,826} & \multirow[t]{2}{*}{1,427} \\
\hline Tinggi & $59(76,6 \%)$ & $29(53,7 \%)$ & & & \\
\hline \multicolumn{6}{|l|}{ 3. Pekerjaan } \\
\hline Tidak bekerja & $47(61,0 \%)$ & $17(31,5 \%)$ & \multirow[t]{2}{*}{0,001} & \multirow[t]{2}{*}{0,293} & \multirow[t]{2}{*}{0,569} \\
\hline Bekerja & $30(39,0 \%)$ & $37(68,5 \%)$ & & & \\
\hline \multicolumn{6}{|l|}{ 4. IMD } \\
\hline Tidak dilakukan & $12(15,6 \%)$ & $30(55,6 \%)$ & \multirow{2}{*}{0,000} & \multirow{2}{*}{6,771} & \multirow{2}{*}{1,899} \\
\hline Dilakukan & $65(84,4 \%)$ & $24(44,4 \%)$ & & & \\
\hline \multicolumn{6}{|l|}{ 5. Dukungan suami } \\
\hline Pasif & $6(7,8 \%)$ & $26(48,1 \%)$ & \multirow[t]{2}{*}{0,000} & \multirow[t]{2}{*}{10,988} & \multirow[t]{2}{*}{1,778} \\
\hline Aktif & $71(92,2 \%)$ & $28(51,9 \%)$ & & & \\
\hline \multicolumn{6}{|l|}{ 6. Pengetahuan } \\
\hline Kurang & $6(7,8 \%)$ & $30(55,6 \%)$ & \multirow[t]{2}{*}{0,000} & \multirow[t]{2}{*}{14,792} & \multirow[t]{2}{*}{2,075} \\
\hline Baik & $71(92,2 \%)$ & $24(44,4 \%)$ & & & \\
\hline \multicolumn{6}{|l|}{ 7. Teknik menyusui } \\
\hline Kurang baik & $37(48,1 \%)$ & $42(77,8 \%)$ & \multirow[t]{2}{*}{0,001} & \multirow[t]{2}{*}{3,784} & \multirow[t]{2}{*}{2,338} \\
\hline Baik & $40(51,9 \%)$ & $12(22,2 \%)$ & & & \\
\hline
\end{tabular}

Keberhasilan menyusui pada dua bulan pertama lebih mungkin didapatkan pada ibu dengan tingkat pendidikan tinggi (OR=2,826; 95\% Cl=1,427), tidak bekerja (OR=0,293; 95\% Cl=0,569), melakukan IMD (OR=6,771; 95\% Cl=1,899), memperoleh dukungan aktif suami (OR=10,988; 95\% Cl=1,778), mempunyai pengetahuan yang baik tentang $\mathrm{ASI}(\mathrm{OR}=14,792 ; 95 \% \mathrm{Cl}=2,075)$ dan menguasai teknik menyusui (OR=3,784; 95\% $\mathrm{Cl}=2,338)$. Bila dilihat dari nilai OR, diantara ketujuh faktor tersebut, faktor dukungan aktif suami dan pengetahuan yang baik mempunyai kemungkinan yang paling tinggi mencapai keberhasilan menyusui.

\section{DISKUSI}

Pengaruh Umur Ibu terhadap Keberhasilan Menyusui pada Dua bulan Pertama

Hasil penelitian ini tidak menemukan adanya pengaruh yang bermakna antara umur ibu dengan keberhasilan menyusui pada dua bulan pertama $(p=0,572)$. Meskipun tidak berpengaruh secara statistik namun dari hasil penelitian terlihat bahwa umur 20-35 tahun merupakan kelompok umur terbanyak yang berhasil menyusui pada dua bulan pertama, yakni sebanyak 64 orang $(83,1 \%)$. Hal tersebut menunjukkan ibu yang berumur 20-35 tahun memiliki kecenderungan yang lebih besar untuk berhasil menyusui pada dua bulan pertama. Hal ini juga menunjukkan bahwa subjek pada penelitian ini sebahagian besar berada pada usia reproduksi sehat, walaupun masih terdapat subjek yang melahirkan di usia yang relatif muda $<20$ tahun dan usia $>35$ tahun yang merupakan faktor risiko terjadinya komplikasi kehamilan, persalinan dan nifas. Ibu yang berumur $<20$ tahun, perkembangan fisik dan psikologisnya cenderung belum siap dan belum stabil untuk hamil, melahirkan serta merawat dan mengasuh bayinya. Ibu yang berumur 35 tahun keatas merupakan faktor risiko untuk hamil dan melahirkan karena fungsi organ reproduksi yang sudah mulai mengendur. Hasil penelitian ini sejalan dengan penelitian yang dilakukan di Banyumas dan Depok yang menunjukkan tidak terdapat hubungan yang bermakna antara umur ibu dengan pemberian ASI eksklusif 6 bulan (11). Hasil ini juga tidak jauh berbeda dengan hasil penelitian yang menunjukkan bahwa ibu yang berusia 25 29 tahun mempunyai peluang 1,52 kali lebih berhasil menyusui eksklusif dibandingkan ibu yang umurnya kurang dari 25 tahun atau lebih dari 30 tahun (12).

Pengaruh Pendidikan terhadap Keberhasilan Menyusui pada Dua Bulan Pertama

Penelitian ini menunjukkan bahwa keberhasilan menyusui pada dua bulan pertama lebih mungkin ditemukan pada ibu dengan pendidikan tinggi. Pendidikan merupakan salah satu faktor yang dapat menunjang kemudahan seseorang untuk dimotivasi kearah yang lebih baik, sehingga diharapkan semakin tinggi tingkat pendidikan ibu maka mempunyai motivasi yang baik dalam mengambil keputusan untuk menyusui bayinya. Seseorang yang mempunyai pendidikan yang lebih tinggi akan lebih mudah menerima informasi, sebaliknya pendidikan yang rendah akan menghambat penafsiran informasi seseorang terhadap objek-objek yang diperkenalkan. Ibu yang berpendidikan tinggi cenderung lebih mudah untuk menerima informasi dan pengetahuan tentang menyusui dibanding yang pendidikannya rendah(13). Hasil penelitian ini didukung oleh penelitian lainnya yang mengemukakan bahwa ada hubungan antara tingkat pendidikan dengan menyusui eksklusif $(7,14-17)$. Penelitian yang dilakukan di Brazil menunjukkan semakin tinggi pendidikan ibu semakin besar peluang untuk menyusui eksklusif. Ibu yang menyelesaikan pendidikan 
dasar mempunyai 2 kali peluang untuk menyusui eksklusif dibanding ibu yang tidak dapat menyelesaikan pendidikan dasar (12). Penelitian serupa juga menunjukkan bahwa pendidikan ibu yang rendah merupakan faktor risiko kegagalan pemberian ASI selama dua bulan.Ibu yang memilliki tingkat pendidikan yang rendah mempunyai peluang 2,8 kali gagal dalam memberikan ASI selama dua bulan dibanding ibu yang memiliki tingkat pendidikan yang tinggi (9).

\section{Pengaruh Status Pekerjaan Ibu terhadap Keberhasilan} Menyusui pada Dua Bulan Pertama

Ibu yang tidak bekerja lebih mempunyai kemungkinan mampu memberikan ASI eksklusif hingga dua bulan pertama. Pada ibu yang bekerja, lama cuti hamil dan melahirkan yang singkat mengakibatkan ibu sudah harus kembali bekerja sebelum masa menyusui eksklusif berakhir. Lain halnya dengan ibu yang tidak bekerja. Ibu yang tidak bekerja mempunyai lebih banyak waktu di rumah untuk mengurus rumah tangga karena tidak terikat dengan jadwal kerja dan rutinitas yang padat, sehingga mempunyai peluang yang lebih besar untuk menyusui secara eksklusif.

Faktor yang menghambat keberhasilan menyusui pada ibu yang bekerja adalah waktu cuti kerja yang pendek, masih kurangnya dukungan dari tempat kerja, pendeknya waktu istirahat saat bekerja sehingga ibu tidak mempunyai cukup waktu untuk memerah ASI, tidak tersedianya ruangan untuk memerah ASI, serta keinginan ibu yang sering bertentangan antara mempertahankan prestasi kerja dan produksi ASI (18). Penelitian lain mengemukakan bahwa salah satu yang faktor yang dapat mempengaruhi pemberian ASI adalah ibu yang bekerja atau mempunyai kesibukan sosial lainnya. Kenaikan tingkat partisipasi wanita dalam angkatan kerja dan adanya emansipasi dalam bidang kerja dan di kebutuhan masyarakat menyebabkan turunnya kesediaan menyusui dan lamanya menyusui (6). Hasil dalam penelitian ini sejalan dengan penelitian lain yang menemukan bahwa status pekerjaan ibu mempunyai hubungan yang bermakna terhadap pemberian ASI eksklusif (7,19-21). Penelitian tentang faktor risiko kegagalan pemberian ASI selama dua bulan juga menemukan bahwa ibu yang bekerja mempunyai risiko 4,5 kali gagal memberikan ASI selama dua bulan kepada bayinya(9). Penelitian di Malaysia menunjukkan bahwa faktor paling dominan yang mempengaruhi pemberian ASI eksklusif adalah status pekerjaan ibu. Ibu yang tidak bekerja berpeluang memberikan ASI ekskusif pada bayinya 3,5 kali dibanding ibu yang bekerja (21).

\section{Pengaruh Pengetahuan terhadap Keberhasilan Menyusui pada Dua Bulan Pertama}

Seorang ibu yang baru pertama kali melahirkan, biasanya lebih protektif terhadap bayinya. Ibu kadangmudah terpengaruh terhadap berbagai provokasi baik dari dalam keluarga maupun dari luar atau lingkungannya sehingga membuat ibu menjadi kurang termotivasi untuk menyusui bayinya. Ibu yang mendapatkan informasi/pengetahuan yang baik tentang menyusui maka tidak mudah terpengaruh. Sejak masa kehamilan, ibu perlu dibekali dengan pengetahuan tentang manfaat dan keunggulan menyusui, fisiologi laktasi serta bagaimana cara memposisikan dan melekatkan bayi pada payudara. Pengetahuan merupakan hal yang penting untuk terbentuknya tindakan seseorang karena tindakan yang didasari oleh pengetahuan akan lebih baik daripada tindakan yang tidak didasari oleh pengetahuan (22).

Hasil penelitian menunjukkan ibu dengan pengetahuan yang baik tentang ASI mempunyai peluang lebih besar untuk memberikan ASI saja pada dua bulan pertama. Temuan ini sejalan dengan penelitian yang mengemukakan bahwa pengetahuan ibu tentang menyusui berpengaruh besar terhadap praktik pemberian ASI. Ibu yang berpengetahuan baik memiliki besar risiko untuk memberikan ASI 5,7 kali dibandingkan ibu yang pengetahuannya kurang baik $(19,23)$. Penelitian lain menunjukkan bahwa ibu primipara yang memiliki tingkat pengetahuan yang tinggi berhubungan positif dengan lamanya durasi menyusui, hal tersebut tidak ditemukan pada ibu multipara (24). Sebaliknya, penelitian lain tidak mendapatkan hubungan yang bermakna dalam praktek pemberian ASI antara ibu yang mempunyai tingkat pengetahuan yang baik dengan ibu yang mempunyai tingkat pengetahuan yang kurang tentang ASI Eksklusif (25).

\section{Pengaruh IMD terhadap Keberhasilan Menyusui pada Dua} Bulan Pertama

Inisiasi Menyusu Dini atau permulaan menyusu dini adalah adalah kontak kulit bayi dan kulit ibu setelah lahir, yaitu dengan meletakkan bayi diantara kedua payudara ibu dalam satu jam pertama bahkan sampai dua jam. Cara bayi melakukan inisiasi menyusu dini ini dinamakan the breast crawl atau merangkak mencari payudara (26). Penelitian yang dilakukan di 8 kabupaten di Jawa Barat dan Jawa Timur menunjukkan bayi yang diberi kesempatan untuk menyusu dini, dua sampai delapan kali lebih berhasil menyusui sampai usia empat bulan dibandingkan ibu yang tidak berkesempatan untuk menyusu dini (27). Bayi yang diberi kesempatan melakukan IMD, persentase masih menyusunya bayi hingga usia enam bulan adalah $59 \%$ dan bayi usia 12 bulan adalah $38 \%$, sedangkan bayi yang tidak diberi kesempatan untuk inisiasi menyusu dini, persentase masih menyusunya bayi hingga usia enam bulan hanya $19 \%$ dan $8 \%$ untuk bayi usia 12 bulan(28). Hasil penelitian ini sejalan dengan penelitian lain bahwa ada hubungan yang bermakna antara IMD dengan pemberian ASI eksklusif 6 bulan. Ibu yang melakukan IMD berpeluang 2,368 kali berperilaku memberikan ASI eksklusif 6 bulan dibandingkan dengan ibu yang tidak melakukan IMD $(11,19)$. Hal serupa juga didukung oleh penelitian yang dilakukan di Kabupaten Pinrang, makin lama bayi menyusu IMD makin meningkatkan keberhasilan menyusui eksklusif pada ibu primipara (29).

\section{Pengaruh Dukungan Suami terhadap Keberhasilan Menyusui Dua Bulan Pertama}

Dukungan suami dalam proses menyusui sangat penting dalam menumbuhkan rasa percaya diri ibu. Dukungan ini dilakukan dengan memberikan motivasi bahwa ibu dapat berhasil menyusui bayinya dengan baik. Disamping itu suami dapat terlibat secara langsung dalam proses menyusui dengan memberikan bantuan praktis kepada ibu. Suami dapat mengambil peran sebagai perantara dalam menyusui dengan cara menggendong dan membawa bayi pada ibunya. Dengan begitu, bayi juga akan merasakan sentuhan ayahnya. Bantuan lainnya yaitu menyendawakan bayi, mengganti popok, memandikan bayi, dan mendendangkan bayi. Dukungan suami dalam bentuk dukungan emosional dan bantuan praktis lainnya merupakan bentuk dukungan yang paling berarti bagi ibu 
dalam proses menyusui. Ibu pun akan merasa bahwa bukan hanya dirinya saja yang bertanggungjawab terhadap bayinya, tetapi suami pun ikut bertanggungjawab $(8,28)$. Penelitian ini sejalan dengan penelitian yang mendapatkan bahwa terdapat hubungan yang bermakna antara dukungan suami dengan perilaku pemberian ASI eksklusif. Pada ibu yang didukung dengan baik oleh suaminya berpeluang 3,737 kali lebih besar berperilaku memberikan ASI eksklusif 6 bulan dibandingkan dengan ibu yang dukungan suaminya kurang (11). Penelitian lain juga mendapatkan bahwa prevalensi praktik pemberian ASI eksklusif pada kelompok ayah yang mendukung lebih tinggi 2,25 kali dibandingkan dengan kelompok ayah yang tidak mendukung (30). Penelitian di Malaysia mengungkapkan bahwa ibu yang mendapat dukungan dari suaminya, 4 kali lebih berhasil menyusui eksklusif dibandingkan dengan ibu yang tidak mendapat dukungan dari suami (21).

Pengaruh Teknik Menyusui terhadap Keberhasilan Menyusui Dua Bulan Pertama

Teknik menyusui yang benar adalah cara memberikan ASI

\section{DAFTAR PUSTAKA}

1. Almatsier S, Soetardjo S, dan Soekatri M. Gizi Seimbang Dalam Daur Kehidupan. Jakarta: PT. Gramedia Pustaka Utama; 2011.

2. Suradi R. Indonesia Menyusui. Jakarta: Badan Penerbit IDAI; 2010.

3. Pusat Data dan Informasi Departemen Kesehatan. Survey Demografi Kesehatan Indonesia 2006-2007. Jakarta: Depkes RI; 2008.

4. Departemen Kesehatan Republik Indonesia. Pedoman Penyelenggaraan Pelatihan Konseling Menyusui dan Pelatihan Fasilitator Konseling Menyusui. Jakarta: Depkes RI; 2011.

5. Siregar A. Faktor-faktor yang Mempengaruhi Pemberian ASI oleh Ibu Melahirkan. [Tesis]. Universitas Sumatera Utara, Medan. 2004.

6. Mascarenhas LM, Albernaz EP, Silva MB, and Silveira RB. Prevalence of Exclusive Breastfeeding and its Determiners in the First 3 Months of Life in the South of Brazil. Jornal de Pediatria. 2006; 82(4): 289-294.

7. Yuliarti N. Keajaiban ASI-Makanan Terbaik untuk Kesehatan, Kecerdasan dan Kelincahan si Kecil. Yogyakarta: Penerbit Andi; 2010.

8. Welfrod H. Successful Infant Feeding. Winchester, London: Carroll and Brown Limited; 2011.

9. Hikmawati I.Faktor-faktor Risiko Kegagalan Pemberian ASI Selama Dua Bulan. [Tesis]. Universitas Diponegoro, Semarang. 2008.

10. Fikawati $\mathbf{S}$ dan Syafiq A. Kajian Implementasi \& Kebijakan Air Susu Ibu Eksklusif dan Inisiasi Menyusu Dini di Indonesia. Makara Kesehatan. 2010; 14(1): 1724.

11. Ida. Faktor-faktor yang Berhubungan dengan Pemberian ASI Eksklusif 6 Bulan di Wilayah Kerja Puskesmas Kemiri Muka Kota Depok. [Tesis]. Universitas Indonesia, Depok. 2011.

12. Venancio IS and Monteiro CA. Individual and pada bayi yang terdiri dari posisi dan perlekatan pada payudara yang tepat. Teknik menyusui merupakan salah satu faktor yang berhubungan keberhasilan menyusui dan pengeluaran ASI. Kenyamanan dalam menyusu bukan hanya terletak pada kenyamanan ibu, tetapi juga kenyamanan bayi. Kenyamanan dalam menyusui dapat tercipta apabila ibu menyusui dengan teknik yang benar. Teknik menyusui yang benar merupakan kunci keberhasilan dalam menyusui $(31,32)$. Penelitian ini didukung oleh penelitian lain yang melihat adanya hubungan yang signifikan antara teknik menyusui yang benar dengan keberhasilan menyusui pada ibu postpartum (33). Sikap positif ibu, dukungan yang kuat dari keluarga, bonding attachment, dan tidak adanya masalah pada puting juga berhubungan secara bermakna dengan kelangsungan menyusui eksklusif (34).

Dapat disimpulkan bahwa ibu dengan tingkat pendidikan tinggi, tidak bekerja, mempunyai pengetahuan yang baik, melaksanakan IMD, mempunyai dukungan aktif dari suami, memiliki teknik menyusui yang baik dapat meningkatkan keberhasilan menyusui pada dua bulan pertama.

Contextual Determinants of Exclusive Breastfeeding in Sao Paulo, Brazil: A Multilevel Analysis. Public Health Nutrition. 2006; 9(1): 40-46.

13. Mubarak WI. Promosi Kesehatan untuk Kebidanan. Jakarta: Salemba Medika; 2011.

14. Kristiansen AL, Lande B, Verby NC, and Andersen LF.Factors Associated with Exclusife Breastfeeding and Breastfeeding in Norway. Public Health Nutrition. 2010; 13(12); 2087-2096.

15. Matias SL, Rivers LA, and Dewey KG. Determinants of Exclusive Breastfeeding in a Cohort of Primiparous Periurban Peruvian Mothers. Journal of Human Lactation. 2012; 28(1): 45-54.

16. Qiu L, Zhao Y, Binns CW, Lee AH, and Xie X. Initiation of Breastfeeding and Prevalence of Exclusive Breastfeeding at Hospital Discharge in Urban, Sub Urban and Rural Areas of Zhejiang China. International Breastfeeding Journal. 2009; 4(1).

17. Sahab $A B$, Lanes $A$, Fieldman $M$, and Tamim $H$. Prevalence and Predictors of 6 month Exclusive Breastfeeding among Canadian Woman: A National Survey. BMC Pediatrics. 2010; 10(20).

18. Wilar R. Sukses Menyusui Saat Bekerja. Jakarta: Ikatan Dokter Anak Indonesia. 2010.

19. Juliastuti R.Hubungan Tingkat Pengetahuan, Status Pekerjaan Ibu dan Pelaksanaan Inisiasi Menyusu Dini dengan Pemberian ASI Eksklusif. [Tesis]. Universitas Sebelas Maret, Surakarta. 2011.

20. Oliveira LPM, Assis AMO, Gomes GSS, Prado MS, and Barreto ML. Breastfeeding Duration, Infant Feeding and Factors Related to Living Condition in the City of Salfador Brazil. Cadernos de Saúde Pública. 2005; 21(5): 1519-1530.

21. Tan KL. Factors Associated with Exclusive Breastfeeding among Infants Under Six Months of Age in Peninsular Malaysia.International Breastfeeding Journal. 2011; 6(2).

22. Nototmodjo S. Pendidikan dan Perilaku Kesehatan. 
Jakarta: Rineka Cipta; 2003.

23. Kuswati. Beberapa Faktor yang Berpengaruh terhadap Praktik Pemberian ASI oleh Ibu Menyusui Pertama yang dirawat di Rumah Sakit Islam Sultan Agung Semarang. [Tesis]. Universitas Diponegoro, Semarang. 2008.

24. Kronborg $\mathrm{H}$ and Vaeth $\mathrm{M}$.The Influence of Psychosocial Factors on the Duration of Breastfeeding. Scandinavian Journal of Public Health. 2004; 32(3): 210-216.

25. Budihartini R. Tingkat Pengetahuan Ibu, Praktek Menyusui dan Kenaikan Berat Badan Bayi yang Diberi Air Susu Ibu (ASI) Eksklusif. [Tesis]. Universitas Diponegoro, Semarang. 2003.

26. Kronborg $\mathrm{H}$ and Vaeth $\mathrm{M}$. How are Effective Breastfeeding Technique and Pacifier Use Related to Breastfeeding Problems and Duration. BIRTH. 2009; 36(1): 34-42.

27. Fikawati S dan Syafiq A. Hubungan antara Menyusui Segera (Immediate Breastfeeding) dan Pemberian ASI Eksklusif Sampai dengan Empat Bulan. Jurnal Kedokteran Trisakti. 2003; 22(2): 47-55.
28. Roesli U. Inisiasi Menyusu Dini Plus ASI Eksklusif. Jakarta: Pustaka Bunda Grup Puspa Swara; 2008.

29. Mardiana A. Hubungan Lama Menyusu pada Inisiasi Menyusu Dini dengan Keberhasilan Menyusui Eksklusif pada lbu Primipara di RSU Lasinrang Pinrang. [Tesis]. Universitas Padjajaran, Bandung. 2009.

30. Evareny L, Hakimi M, dan Padmawati RS. Peran Ayah dalam Praktik Menyusui. Berita Kedokteran Masyarakat. 2010; 26(4): 187-195.

31. Novianti R. Cara Dahsyat Memberikan ASI untuk Bayi Sehat dan Cerdas. Yogyakarta: Octopus; 2009.

32. Suradi R. Manajemen Laktasi Menuju Persalinan Aman dan Bayi Lahir Sehat. Jakarta: Perinasia; 2003.

33. Utari MD dan TobingCL. Hubungan Teknik Menyusui terhadap Keberhasilan Menyusui pada Ibu Postpartum di Rumah Bersalin Delima Tembung Medan. [Repository]. Universitas Sumatra Utara, Medan. 2012

34. Cernadas JC, Noceda G, Barrera L, Martinez AM, and Garsd A. Maternal and Perinatal Factors Influencing the Duration of Exclusive Breastfeeding during the First Six Months of Life. Journal of Human Lactation. 2003; 19(2): 136-144. 